\title{
DOE/MT/92021--TS
}

Technical Progress Report No.14

\section{Analysis/Control of In-Bed Tube Erosion \\ Phenomena in the Fluidized Bed \\ combustion (FBC) system}

\author{
to \\ U.S. Department of Energy \\ Pittsburgh Energy Technology Center \\ P.O. Box 10940, MS 921-118 \\ Pittsburgh, PA 15236-0940 \\ for
}

Project No: DE-FG22-92MT92021

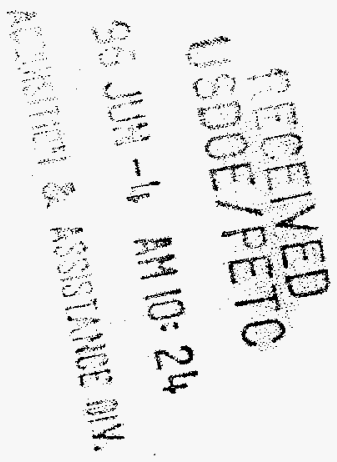

\author{
by \\ Dr. Seong W. Lee, Principal Investigator

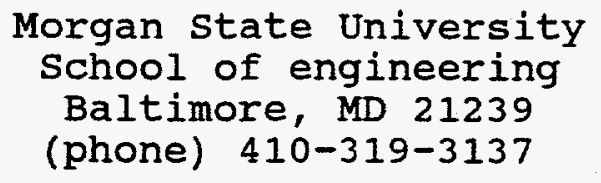 \\ April 1996




\section{DISCLAIMER}

Portions of this document may be illegible in electronic image products. Images are produced from the best available original document. 
SUMMARY

This technical report summarizes the research work performed and progress achieved during the period of January 1, 1996 to March 31, 1996.

The material wastage tests were continued to analyze erosion phenomena under the simulated erosion conditions of inbed tubes in FBC. AISI 1018 steel and three thermal sprayed coating specimens were tested at an elevated temperature $\left(300{ }^{\circ} \mathrm{C}\right)$ using nozzle type erosion tester.

Bed ashes retrieved from the operating biomass-fired boiler were used for erodent particles at a particle loading of $375 \mathrm{~g}$, at particle impact angle of $30^{\circ}$, at particle velocity $60 \mathrm{~m} / \mathrm{s}$ for exposure periods of 4 hours. The specimens were water-cooled on the backside. The material wastage of specimens was determined by thickness measurements.

Test results can be seen that the cooled specimen had greater material wastage than that of the uncooled specimens. In addition, all of thermal-sprayed coating specimens for both cooled and uncooled specimens could reduce the erosion wastage rates as compared with 1018 steel. Among the three thermalsprayed coatings, a DS-105 specimen of high velocity oxygen fuel spraying exhibited the lowest erosion wastage rate.

When tested a higher particle velocity $(60 \mathrm{~m} / \mathrm{s})$, but at the same elevated temperature $\left(300^{\circ} \mathrm{C}\right)$, the material wastage rate of all three coatings was about 6 to 18 times higher than that of the material wastage at a low particle velocity $(2.5 \mathrm{~m} / \mathrm{s})$. 
SUMMARY $\ldots \ldots \ldots \ldots \ldots \ldots \ldots \ldots \ldots \ldots \ldots \ldots \ldots \ldots \ldots \ldots \ldots \ldots$

\section{SECTION}

1. Effect of Cooled Thermal-Sprayed Coatings on In-Red Tube Erosion at a High Particle velocity in FBC............

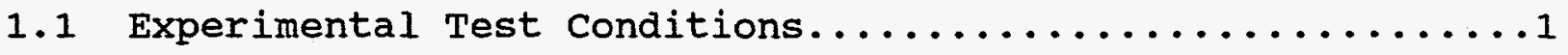

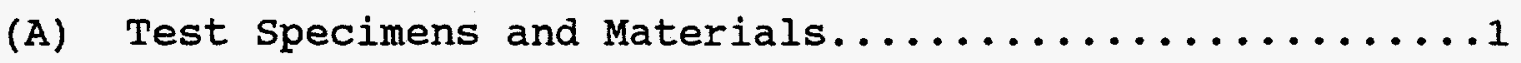

(b) Test Conditions and Material Wastage Measurements....4

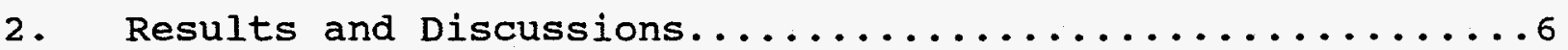

2.1 Erosivity of Erodent Particles................

2.2 Material Wastages/Their Ranking for Different Test

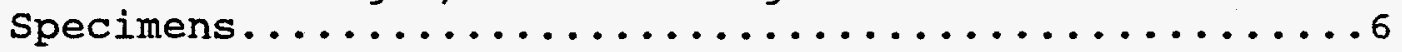

2.3 Effect of Particle Impact Velocity.............

REFERENCES......................... 


\section{SECTION 1}

EFFECT OF COOLED THERMAL-SPRAYED COATINGS ON IN-BED TUBE EROSION AT A HIGH PARTICLE VELOCITY IN FBC

Material wastage of in-bed tubes in atmospheric fluidizedbed combustor ( $A F B C$ ) continues to be an important issue. In our previous work [1], the erosion.phenomena of AISI 1018 steel and several thermal sprayed coatings under simulated in-bed tube erosion conditions of FBCs was studied. The actual service heat exchanger tubes are usually cooled by water or steam being heated [2]. So, the cooled specimens were tested to observe the material wastage and its mechanism under different test conditions [1].

In this work, tests were continued to analyze the erosion phenomena of the cooled specimen at high particle velocity (60 $\mathrm{m} / \mathrm{s})$, which was compared with the results of the isothermal specimens.

\subsection{EXPERIMENTAL TEST CONDITIONS}

(A) Test Specimens and Materials

The target materials for the test were three thermal sprayed coatings, DS200,DS105, Rokide C, and AISI 1018 steel. The characteristics of each target coating material was introduced in the previous report [1]. Bed ashes retrieved from the operating biomass-fired boiler were used for erodent particles. Table 1 shows different compositions and phases of the bed ash particles.

The shape of the bed ash particles is shown in Figure 2 . The mean particle size was $421 \mu \mathrm{m}$ with a mean particle density of 


\begin{tabular}{|c|c|c|c|c|c|c|c|c|c|c|c|c|}
\hline Element & $\mathrm{O}$ & $\mathrm{Si}$ & $\mathrm{Al}$ & $\mathrm{Mg}$ & $\mathrm{S}$ & $\mathrm{K}$ & $\mathrm{Ca}$ & $\mathrm{Ti}$ & $\mathrm{Fe}$ & $\mathrm{Na}$ & $\mathrm{P}$ & $\mathrm{Cl}$ \\
\hline Chem. & 45.28 & 33.69 & 5.74 & 1.008 & 0.029 & 5.602 & 4.981 & 0.215 & 1.39 & 1.706 & 0.358 & - \\
\hline EDS & 47.6 & 31.68 & 6.45 & 1.01 & 0.04 & 5.14 & 4.59 & 0.4 & 1.13 & 1.02 & 0.95 & 0.59 \\
\hline Phase & \multicolumn{8}{c|}{$\mathrm{SiO}_{2}($ Quart $),\left(\mathrm{Na}_{2} \mathrm{~K}_{\mathrm{ASSi}} \mathrm{O}_{8}\right.$ (Anorthoclase), $\mathrm{NaAlSi}_{3} \mathrm{O}_{8}$ (Albite) } \\
\hline
\end{tabular}

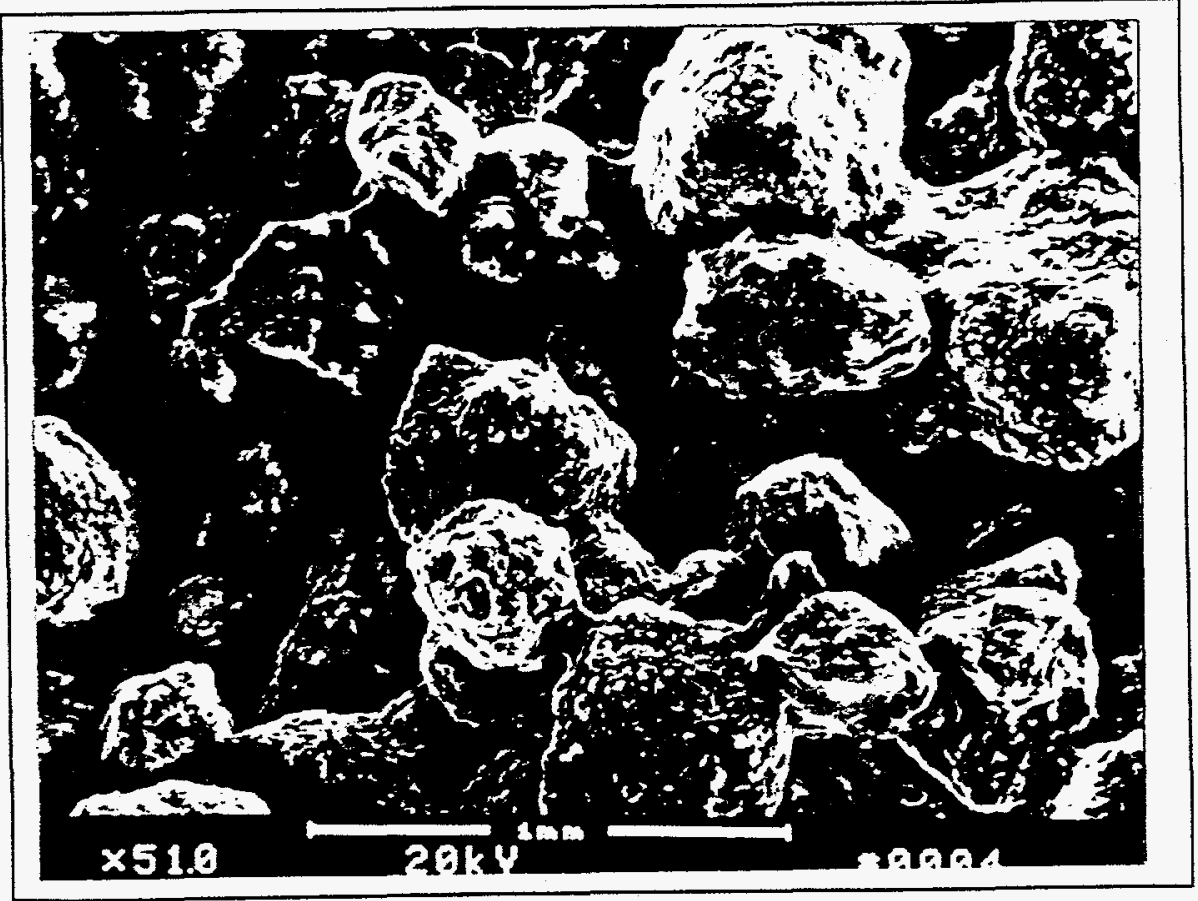

Figure 1 Particle Appearance of Bed Ash 
Ave. 421 microns, Density $2439 \mathrm{~kg} / \mathrm{m} 3$

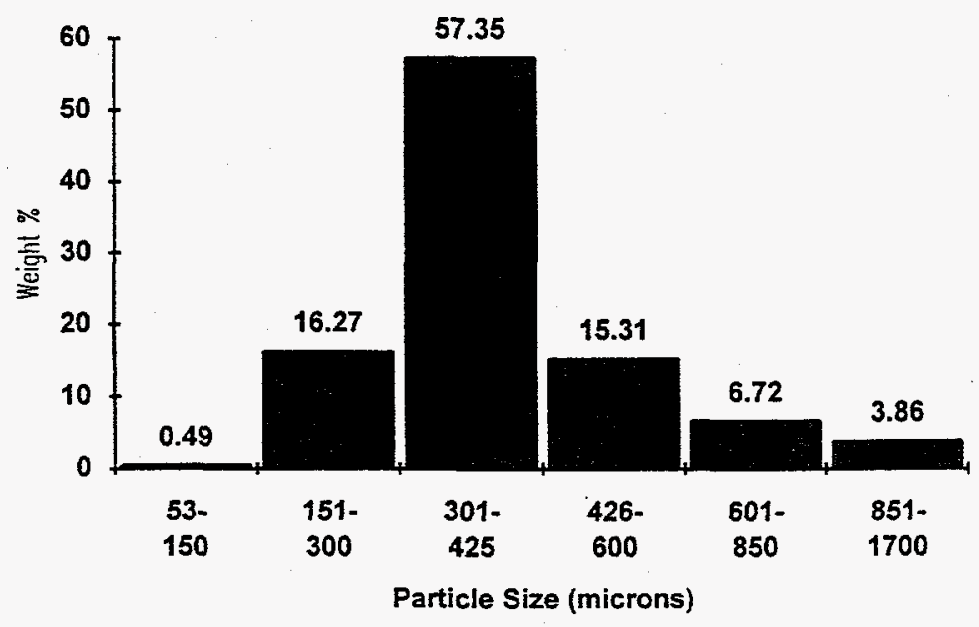

Figure 2. Particle size distribution for bed ash A3.

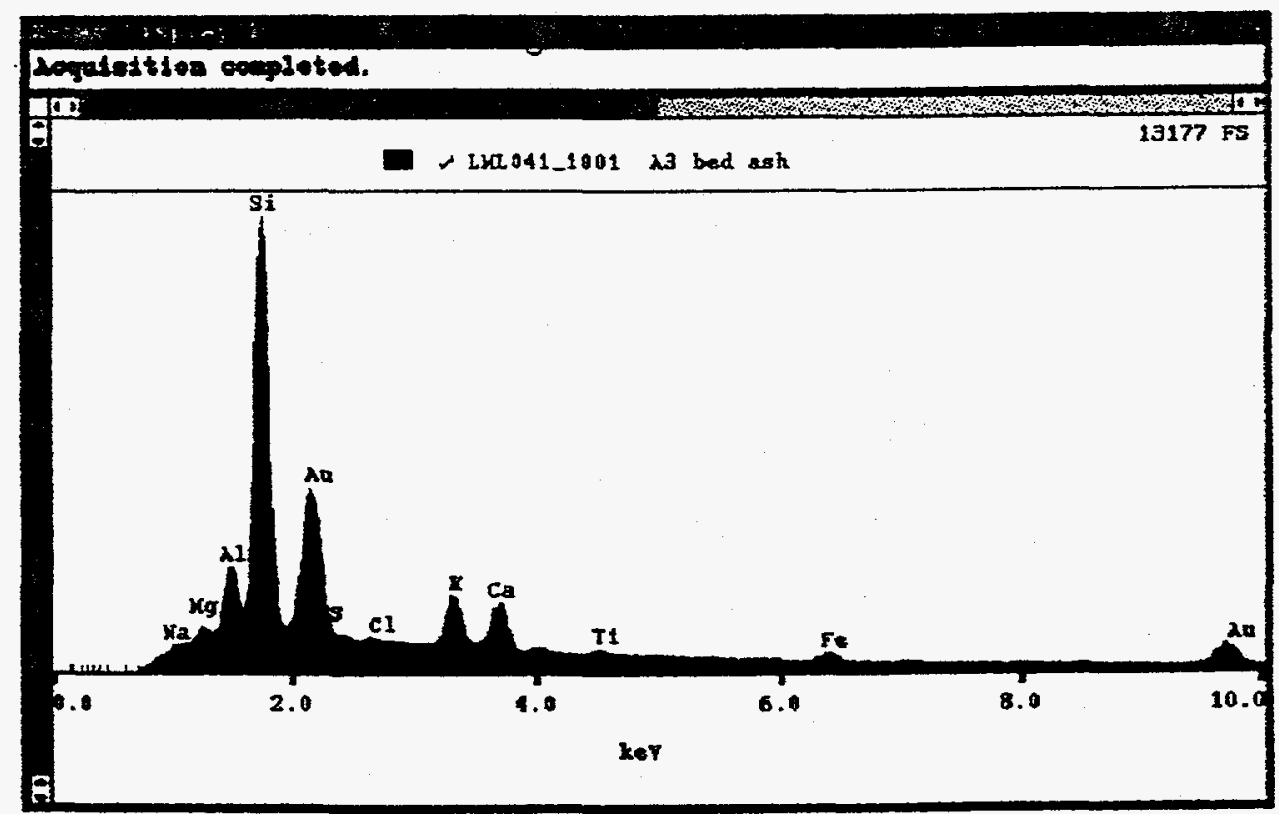

Figure 3. EDS spectra collected from the bed ash. 
$2439 \mathrm{~kg} / \mathrm{m}^{3}$. The particle size distribution is shown in Figure 2. These particles are mainly consisted of silica with a little amount of other elements, which is shown in the results of energy dispersive spectrometry (EDS) of Figure 3 .

(B) Test Conditions and Material Wastage Measurements

The tests of material wastage were carried out in the elevated temperature blast nozzle type of tester [1]. In the test facility, erodent particles flow down a vibrating tube into a chamber, where they impact the test specimens. The temperature ranges in the tester were achievable from $20^{\circ} \mathrm{C}$ to $850{ }^{\circ} \mathrm{C}$. Two different conditions for the specimens were applied by cooled specimen and isothermal specimen. The surface of the specimen was exposed directly to the environmental temperature, $750{ }^{\circ} \mathrm{C}$ while the backsides of specimens were water-cooled.

The high particle velocity $(60 \mathrm{~m} / \mathrm{s})$ was applied to compare with the results of low particle velocity condition [1]. Tests were carried out at a specimen surface temperature of $300{ }^{\circ} \mathrm{C}$, using impact angle of $30^{\circ}$. In our previous work [1], it was found that all tested coatings exhibited "ductile behavior" as that of steep impact angle. Thus, this work focused on material wastage at a shallow impact angle, $30^{\circ}$. The test time of 4 hours was used at particle loading of $375 \mathrm{~g}$.

The material wastage of the specimens was determined by thickness measurements. The microscopic dimensional measurements of cross-sections of the area of greatest material loss were 
applied to determine the thickness of the remaining sound metal. The measurement of the thickness change was considered to be more valid measurement of the material wastage because the weight measurement included material erosion wastage, the remaining oxide scale, and ash deposition. The material wastage conditions were summarized in Table 2 .

Table 2. Material Wastage Test Conditions

\begin{tabular}{|l|l|}
\hline Particle Velocity & $60 \mathrm{~m} / \mathrm{s}$ \\
\hline Particle Impact Angle & $30^{\circ}$ \\
\hline Bed Particle Loading & $375 \mathrm{~g}$ \\
\hline Erodent Particle & Bed Ash A3 \\
\hline Environmental Temperature & $750^{\circ} \mathrm{C}$ \\
\hline Specimen Surface Temperature & $300^{\circ} \mathrm{C}$ \\
\hline Testing Time & 4 hours \\
\hline
\end{tabular}


SECTION 2

\section{RESULTS AND DISCUSSIONS}

\subsection{Erosivity of Erodent Particles}

Bed ashes retrieved from the operating biomass-fired boiler demonstrated high erosivity, which is characterized by low ash and low sulfur contents. Thus, the erosion potential of the fuel is relatively low. However, other media is added into the combustor in order to provide a sufficient amount of circulating material. Typically sand (silica quartz) is used which has been shown to increase the erosion wastage [4]. Chemical analysis and EDS spectra results confirmed the high concentration of silica quartz in bed ash particles as shown in Table 1 and Figure 3 .

The high erosivity of these ash particles can also be related to their larger mean particle size and to the presence of "chemically active" compounds in the ash particles. Such compounds contain potassium (K), sodium (Na), phosphorous (P), and chlorine (CI) which increased the material wastage [5].

\subsection{Material Wastages and Their Ranking for Different Test Specimens}

Material wastage results compared with the data of isothermal specimens (uncooled specimens) as shown in Figure 4 . It can be seen that the cooled specimen had greater material wastage than that of the uncooled specimens. The data shows that the cooled 1018 steel specimen lost the highest thickness, while the thickness loss of cooled coating specimens had less increase compared to that of uncooled coating specimens. It seems that the effect 


\begin{tabular}{|c|c|c|c|c|}
\hline \multirow{3}{*}{$\begin{array}{c}\text { Target } \\
\text { Material }\end{array}$} & \multicolumn{4}{|c|}{ Material wastage(thickness loss) } \\
\cline { 2 - 5 } & \multicolumn{2}{|c|}{ Cooled specimens } & \multicolumn{2}{|c|}{ Isothermal specimens } \\
\cline { 2 - 5 } & $\mu \mathrm{m}$ & Rate $(\mu \mathrm{m} / \mathrm{g})$ & $\mu \mathrm{m}$ & Rate $(\mu \mathrm{m} / \mathrm{g})$ \\
\hline \hline 1018 & 494 & 1.317 & 306 & 0.816 \\
\hline DS-200 & 48 & 0.128 & 38 & 0.101 \\
\hline DS-105 & 28 & 0.0747 & 18 & 0.048 \\
\hline Rokide C & 32 & 0.0853 & 23 & 0.0613 \\
\hline
\end{tabular}

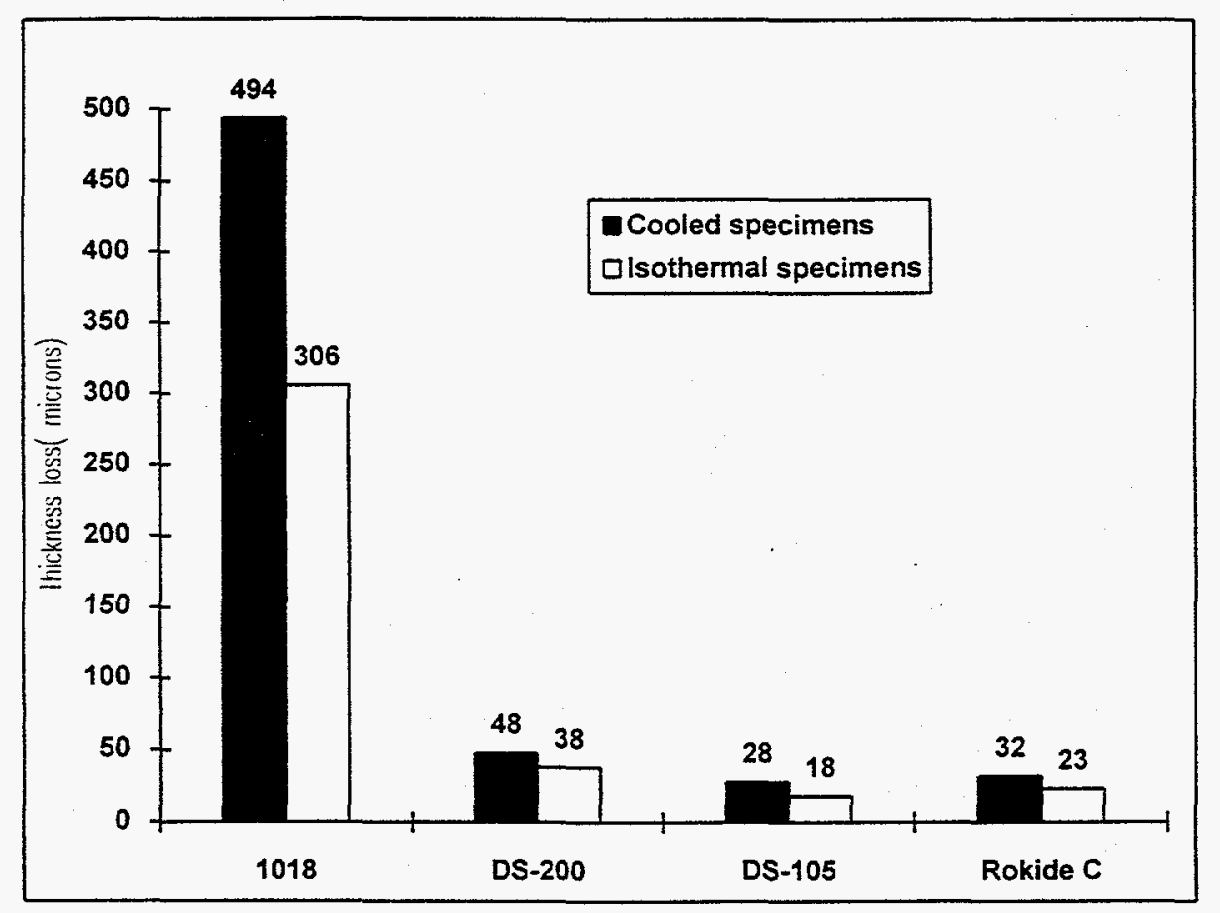

Figure 4. Comparison of erosion wastage data. 
of cooling specimen on the erosion wastage for 1018 steel is greater than that for thermal sprayed coatings. The test results also indicated that all of thermal-sprayed coating specimens for both cooled and uncooled specimens reduced the erosion wastage as compared with 1018 steel. In comparison to the testing for both the cooled and uncooled specimen showed the same ranking of the material wastage rate. Among the three thermal-sprayed coatings, the $\mathrm{Cr}_{3} \mathrm{C}_{\hat{2}}$ coating of high velocity oxygen fuel spraying (DS105) exhibited the lowest erosion wastage rate as shown in Figure 4 .

\subsection{Effect of Particle Impact Velocity}

For the low particle velocity $(2.5 \mathrm{~m} / \mathrm{s})$, the oxidation of surrounding surfaces after 96 hours was combined with very low erosion wastage rates $[1,3]$. At the low velocity, the oxide scale-particle deposition layer developed at low elevated temperature condition $\left(300^{\circ} \mathrm{C}\right)$, which causes less wastage loss [3].

When tested a higher particle velocity $(60 \mathrm{~m} / \mathrm{s})$, but at the same elevated temperature, the metal wastage dramatically increased to $494 \mathrm{\mu m}$ for cooled 1018 steel, which was 20 times higher than that of cooled 1018 steel at low particle velocity $(2.5 \mathrm{~m} / \mathrm{s})$. For the higher velocity $(60 \mathrm{~m} / \mathrm{s})$, the material wastage rate of all three coatings was about 6 to 18 times higher than that of the material wastage at a low particle velocity $(2.5$ $\mathrm{m} / \mathrm{s})$. A possible reason for this is the influence of particle velocity on metal wastage: particle energy, at a higher velocity, is sufficient to cause a continuous increase of the material removal rate $[6]$. 


\section{REFERENCES}

[1] Lee, S.W., Technical Progress Reports, Nos. 7 to 12, U.S. DOE, Pittsburgh Energy Technology Center (PETC), $1994 / 1995$.

[2] Stringer, J. et al., Wastage in Bubbling Fluidized-Bed Combustors: An Update, Proc. 10th Intl. Conf. on FBC, ASME, New York, NY, 1989, pp.857-862.

[3] Lee, S.W., Technical Progress Report, No. 13, U.S. DOE, PETC, January 1996.

[4] Mylchreest, D. and Bultler, J., Proceedings of 7 th Annual Fluidized Bed Conference, CIBO, December 1991, pp. 131-143.

[5] Wang, B.Q. and K. Luer, The Relative Erosion-Corrosion Resistance of Commercial Thermal sprayed coatings in a Simulated CFBC Environment, Proc. of th 7 th thermal spray Conference, 1994, pp. 115-120.

[6] Lee, S.W. and B.Q. Wang, Erosion of AISI1018 steel and Several Thermal sprayed Coatings under simulated In-bed Tube Erosion Conditions of FBCs, Proc. of 13th Int. Conf. on FBC. Vol.2, 1995, pp. 1427-1432.

\section{DISCLAIMER}

This report was prepared as an account of work sponsored by an agency of the United States Government. Neither the United States Government nor any agency thereof, nor any of their employees, makes any warranty, express or implied, or assumes any legal liability or responsibility for the accuracy, completeness, or usefulness of any information, apparatus, product, or process disclosed, or represents that its use would not infringe privately owned rights. Reference herein to any specific commercial product, process, or service by trade name, trademark, manufacturer, or otherwise does not necessarily constitute or imply its endorsement, recommendation, or favoring by the United States Government or any agency thereof. The views and opinions of authors expressed herein do not necessarily state or reflect those of the United States Government or any agency thereof. 